Biochimica et Biophysica Acta, 398 (1975) 415-423

(C) Elsevier Scientific Publishing Company, Amsterdam - Printed in The Netherlands

BBA 56652

\title{
ACTION OF PHOSPHOLIPASES ON THE PHOSPHATIDYLCHOLINE EXCHANGE PROTEIN FROM BEEF LIVER
}

H.H. KAMP, E.D. SPRENGERS, J. WESTERMAN, K.W.A. WIRTZ and L.L.M. VAN DEENEN

Laboratory of Biochemistry, State University of Utrecht, University Centre "De Uithof",

Padualaan 8, Utrecht (The Netherlands)

(Received February 12th, 1975)

\section{Summary}

The phospholipases $A_{2}, C$ and $D$ have been used to investigate the localization of phosphatidylcholine in the phosphatidylcholine exchange protein from beef liver. The rate of enzymatic hydrolysis of the protein-bound phosphatidylcholine was found to be very low. Addition of deoxycholate, isobutanol or dioxane to the native protein, under conditions where delipidation did not occur, greatly enhanced the hydrolytic action of the phospholipases. From these results it is concluded that phosphatidylcholine may be buried in the protein molecule.

\section{Introduction}

The phosphatidylcholine exchange protein from beef liver contains one molecule of phosphatidylcholine which can be extracted with organic solvents $[1,2]$ and as demonstrated in the preceding paper [3], with detergents at concentrations above the critical micelle concentration. In the present study the exchange protein has been incubated with phospholipases in order to obtain information on the localization of the phosphatidylcholine molecule. In general, phospholipases have been very useful in elucidating the disposition of phospholipids in biological membranes [4-10] and serum lipoproteins [1114]. Besides investigating the native exchange protein, phospholipases have been used also in this study to determine how deoxycholate, isobutanol and dioxane affect the accessibility of the endogenous phosphatidylcholine molecule towards enzymatic action under conditions where the phosphatidylcholine remains on the protein.

Detergents and organic solvents are able to disrupt lipid-protein interactions in serum lipoproteins $[15,16]$ and biological membranes $[17-23]$. It is thought that detergent [24] and organic solvent molecules [25] compete with the lipids for the hydrophobic sites on the proteins. Below the critical micelle 
concentration deoxycholate, for example, will interact with lipid protein complexes without actual delipidation taking place [22,26]. A similar interaction may occur with organic solvents like $n$ - and isobutanol which have distinct hydrophobic and hydrophilic regions [25]. The hydrophobic character of these compounds is reflected in the relatively low solubility in water. Dioxan is completely miscible with water and very effectively lowers the dielectric constant. Below $15 \mathrm{vol} \%$ this solvent will not in general influence the native structure of a protein [27]. However, increasing the dioxane concentration may give rise to an unfolding of the protein through the disruption of hydrophobic bonds which play an important role in dictating the tertiary structure of a protein $[28,29]$.

Previous studies $[30,31]$ from this laboratory have shown that phospholipases evoke hemolysis of erythrocytes in the presence of sublytic concentrations of sodium deoxycholate. In this study, it is demonstrated that deoxycholate, isobutanol and dioxan greatly facilitate the hydrolytic action of phospholipases towards the endogenous phosphatidylcholine molecule bound to the exchange protein.

\section{Materials and Methods}

Phosphatidylcholine exchange protein from beef liver, $\left[\mathrm{Me}^{-14} \mathrm{C}\right]$ phosphatidylcholine exchange protein (spec. act. $15 \mathrm{Ci} / \mathrm{mol}$ ), phosphatidylcholine from egg yolks, $\left[\mathrm{Me}^{1{ }^{4}} \mathrm{C}\right]$ phosphatidylcholine (spec. act. $62 \mathrm{Ci} / \mathrm{mol}$ ) and lysophosphatidylcholine were obtained as previously described [3]. Phospholipase $\mathrm{A}_{2}$ from Naja naja, phospholipase $\mathrm{C}$ from Bacillus cereus and Clostridium welchii, and phospholipase $\mathrm{D}$ from cabbage leaves were purified and kindly donated by Dr R.F.A. Zwaal. Phospholipase $A_{2}$ from porcine pancreas was a gift of $\mathrm{Dr}$ G.H. de Haas. Phospholipase $A_{2}$ from bee venom (Fluka, Switzerland) was used without further purification. Isobutanol and sodium deoxycholate were analytical grade and were used without further purification. 1,4-Dioxan was distilled from solid potassium hydroxide and ferrous sulfate to remove peroxides. Phosphatidylcholine exchange activity was assayed in the liposome-microsome assay as described previously [1]. Electrophoresis on polyacrylamide gels was carried out according to the method of Davis [32]. Staining and slicing of the gel were performed as published [3].

Treatment with deoxycholate, dioxan and isobutanol

$\left[{ }^{1} \mathrm{C}\right]$ Phosphatidylcholine exchange protein $(10-20 \mu \mathrm{g}$ protein per $\mathrm{ml})$ is present in $0.05 \mathrm{M}$ Tris/0.05 $\mathrm{M} \mathrm{NaCl} / 0.02 \% \mathrm{NaN}_{3}$ (pH 7.4). Solutions containing different amounts of deoxycholate or dioxan are prepared in the same buffer and then mixed with the protein in a final volume of $2 \mathrm{ml}$. The samples were incubated for $30 \mathrm{~min}$ at $37^{\circ} \mathrm{C}$ and subsequently assayed for their susceptibility to phospholipase action.

Because of its poor miscibility with water, isobutanol is introduced into the protein sample by dialysis overnight at room temperature. An aliquot of the ${ }^{14} \mathrm{C}$-labelled protein stock solution $(15 \mathrm{ml})$ is dialysed against Tris/ $\mathrm{NaCl} /$ 
$\mathrm{NaN}_{3}$ buffer (1 l) containing the desired concentration of isobutanol. Prior to incubation with the phospholipases, $1.3-\mathrm{ml}$ aliquots of the dialysate are made up to $2 \mathrm{ml}$ with the dialysis buffer in order to normalize the concentration of exchange protein during all treatments.

The effects of the above treatments on the phosphatidylcholine exchange activity has been determined with unlabelled exchange protein. Aliquots $(50-100 \mu \mathrm{l})$ of these treated protein samples were added to the assay system containing ${ }^{14} \mathrm{C}$-labelled microsomes and liposomes in a total volume of $2.5 \mathrm{ml}$ [1]. In this way, small amounts of deoxycholate, isobutanol and dioxan are introduced into the assay medium. With untreated protein it was shown that these amounts had no effect on the exchange activity and did not affect the blanko incubations.

Hydrolysis of $\left[\mathrm{Me}^{-14} \mathrm{C}\right]$ phosphatidylcholine bound to the exchange protein The protein samples present in $2 \mathrm{ml}$ Tris $/ \mathrm{NaCl} / \mathrm{NaN}_{3}$ buffer ( $\mathrm{pH} 7.4$ ) which were treated as described above are incubated at $37^{\circ} \mathrm{C}$ with a number of phospholipases.

A. The hydrolytic action of phospholipase $A_{2}$ from porcine pancreas and bee venom is measured in the presence of $0.001 \mathrm{M} \mathrm{CaCl}_{2}$; that of phospholipase $\mathrm{A}_{2}$ from Naja naja in the presence of $0.01 \mathrm{M} \mathrm{CaCl}_{2}$. The reaction is terminated by addition of a 5 -fold excess of EDTA. With zero-time incubations, inhibitor is added prior to the enzyme. After inhibition the samples are extracted according to the method of Bligh and Dyer [33]. Phosphatidylcholine $(1.5 \mu \mathrm{mol})$ and lysophosphatidylcholine $(1.5 \mu \mathrm{mol})$ are added to each sample as carriers. The extracted lipids are applied quantitatively to thin-layer plates (Silica gel G, Merck, Germany) and separated chromatographically using the solvent system chloroform/methanol/acetic acid/water (25:15:4:2, $\mathrm{v} / \mathrm{v})$. Radioactive spots coinciding with phosphatidylcholine and lysophosphatidylcholine were localized with a Panax scanner. The spots containing $\left[{ }^{14} \mathrm{C}\right]-$ phosphatidylcholine were scraped off, transferred to small columns, and eluted with chloroform/methanol $(1: 1, \mathrm{v} / \mathrm{v})$. The eluted lipids were concentrated to dryness in vacuo, dissolved in $0.3 \mathrm{ml}$ methanol, and mixed with $16 \mathrm{ml}$ of toluene (0.5\% PPO, $0.03 \%$ POPOP). Radioactivity was measured with a Packard Tricarb liquid scintillation spectrometer and corrected to $100 \%$ absolute efficiency. The $\left[{ }^{14} \mathrm{C}\right]$ phosphatidylcholine recovered is expressed in percent relative to the radioactivity recovered after zero-time incubation. The decrease of this ${ }^{14} \mathrm{C}$ label is taken as a measure of phospholipid hydrolysis.

B. The hydrolytic action of phospholipase $\mathrm{C}$ from $C$. welchii is measured in the presence of $0.001 \mathrm{M} \mathrm{CaCl}_{2}$ and $0.0004 \mathrm{M} \mathrm{ZnCl}_{2}$; that of phospholipase $\mathrm{C}$ from $B$. cereus in the presence of $0.001 \mathrm{M} \mathrm{CaCl}_{2}$, and that of phospholipase $\mathrm{D}$ from cabbage leaves in the presence of $0.01 \mathrm{M} \mathrm{CaCl}_{2}$. The incubations with the phospholipases $\mathrm{C}$ are inhibited by addition of a 5-fold excess of EDTA and $2 \mathrm{mg}$ phenantroline chloride (Merck, Germany). Phospholipase $\mathrm{D}$ action is inhibited with only EDTA. With the zero-time incubations the inhibitors are added prior to the enzyme. After inhibition the samples are extracted according to the method of Bligh and Dyer [33] in the presence of $1.5 \mu \mathrm{mol}$ of phosphatidylcholine added as carrier. The extracts are concentrated to dryness in vacuo, and the radioactivity determined as described above. 
Results

\section{Effect of sodium deoxycholate}

$\left[\mathrm{Me}^{-1}{ }^{4} \mathrm{C}\right.$ ] Phosphatidylcholine exchange protein $(13 \mu \mathrm{g}$ of protein) is incubated with sodium deoxycholate at concentrations between 0.01 and $0.08 \%$ $(\mathrm{w} / \mathrm{v})$ as described in Materials and Methods. In this concentration range deoxycholate does not delipidate the exchange protein as monitored by means of polyacrylamide gel electrophoresis according to the method described in the previous study [3]. Moreover, no adverse effect was detected on the exchange activity of the protein fractions due to the detergent treatment. However, incubations with phospholipases demonstrated that deoxycholate makes phosphatidylcholine present in the exchange protein available for enzymatic hydrolysis (Figs 1 and 2).

It is shown in Fig. $1 \mathrm{~A}$ and $\mathrm{B}$ that in the absence of deoxycholate phospholipase $\mathrm{A}_{2}$ from bee venom and phospholipase $\mathrm{C}$ from $B$. cereus hydrolyze the protein-bound phosphatidylcholine at a very low rate only. For each enzyme the rate of hydrolysis already appears to be maximal, as increasing the enzyme concentration has no further effect. Incubation in the presence of deoxycholate greatly enhances the hydrolytic action of these phospholipases towards phosphatidylcholine on the exchange protein. For both enzymes, under conditions where delipidation of the protein does not occur, the rate of hydrolysis increases with increasing deoxycholate concentration. Electrophoresis of exchange protein on polyacrylamide gels after incubation with phospholipase $\mathrm{A}_{2}$ in the presence of $0.05 \%$ deoxycholate, demonstrated that at least one of the hydrolysis products formed i.e. $\left[{ }^{14} \mathrm{C}\right]$ lysophosphatidylcholine remained bound to the protein.

In order to determine whether other phospholipases would hydrolyze the endogenous phosphatidylcholine, the activity of phospholipase $A_{2}$ from porcine pancreas (Fig. 2A), phospholipase $\mathrm{A}_{2}$ from $N$. naja (Fig. 2B), phospholipase D from cabbage leaves (Fig. 2C) and phospholipase $\mathrm{C}$ from $C$. welchii (Fig. 2D) were assayed in the absence and presence of $0.05 \%$ deoxycholate. It is scen that in the absence of detergent all phospholipases hydrolyze the phos-

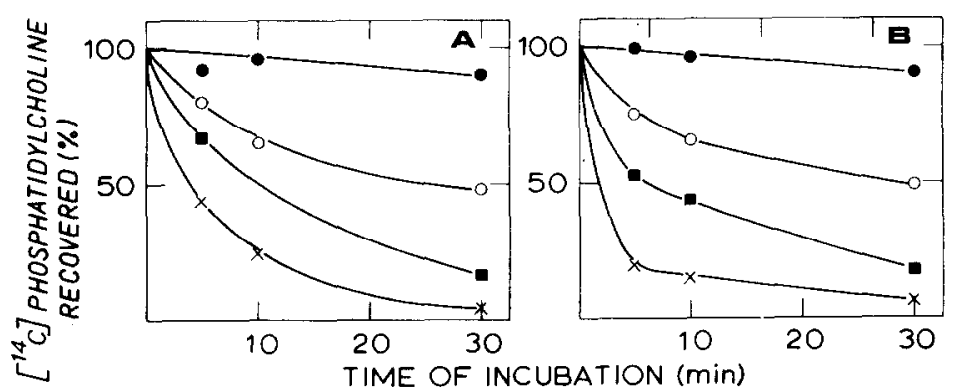

Fig. 1. The effect of deoxycholate on the hydrolysis of $\left[{ }^{14} \mathrm{C}\right]$ phosphatidylcholine, bound to the exchange protein, by phospholipase $\mathrm{A}_{2}$ from bee venom (Fig. 1A) and phospholipase $\mathrm{C}$ from $B$. cereus (Fig. 1B). Incubations contained $13 \mu \mathrm{g}$ of radiolabelled exchange protein (spec. act. $15 \mathrm{Ci}^{-} \mathrm{mol}^{-1}$ i.e. $0.6 \mathrm{nmol}^{-}$ of phosphatidylcholine), $0.2 \mu \mathrm{g}$ phospholipase $\mathrm{A}_{2}$ or $1 \mu \mathrm{g}$ phospholipase $\mathrm{C}$ (1 unit). Incubations were carried out as described in Materials and Methods. $\longrightarrow \longrightarrow, 0 \%$ deoxycholate; $0-1,0.01 \%$; $-\quad, 0.03 \% ; X-X, 0.05 \%$ (Fig. $1 \mathrm{~A}$ ) and $0.08 \%$ (Fig. 1B). 

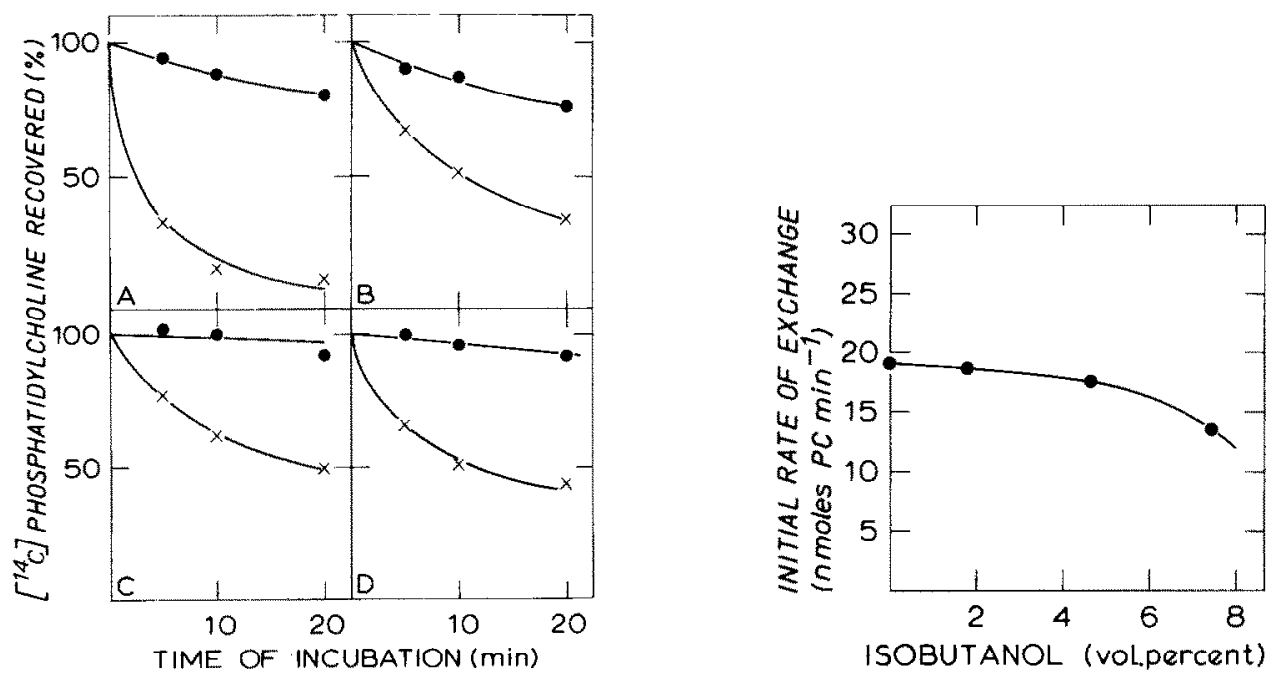

Fig. 2. Hydrolysis of $\left[{ }^{14} \mathrm{C}\right]$ phosphatidylcholine bound to the exchange protein by phospholipases in the absence (-—) or in the presence of $0.05 \%$ deoxycholate $(X-C-X) .17 \mu \mathrm{g}$ radiolabelled exchange protein (spec. act. $15 \mathrm{Ci} \cdot \mathrm{mol}^{-1}$ i.e. $0.8 \mathrm{nmol}$ of phosphatidylcholine) is incubated with 1.25 unit of phospholipase $A_{2}$ from porcine pancreas (Fig. $2 \mathrm{~A}$ ); 1.25 units of phospholipase $\mathrm{A}_{2}$ from $N$. naja (Fig. 2B); 2.0 units of phospholipase $D$ from cabbage leaves (Fig. 2C) and 1.25 units of phospholipase $C$ from C. welchii (Fig. 2D). Incubations were carried out as described in Materials and Methods.

Fig. 3. The effect of isobutanol on the exchange activity of the exchange protein. Samples of $50 \mu$ containing protein $(1.5 \mu \mathrm{g})$ and different concentrations of isobutanol were transferred to a liposomemicrosome system $\left(2.5 \mathrm{ml}\right.$ tolal volume). The initial rate of exchange was measured at $37^{\circ} \mathrm{C} . \mathrm{PC}, \mathrm{phospha-}$ tidyleholine.

phatidylcholine molecule at a low rate. This rate was found to be independent of the enzyme concentration. However, in all instances the presence of deoxycholate greatly enhanced the susceptibility of protein-bound phosphatidylcholine to the hydrolytic action of these phospholipases.

\section{Effect of isobutanol}

Isobutanol had been introduced into the solution containing the exchange protein by dialysis overnight at room temperature (see Materials and Methods). This had the advantage that at no time the exchange protein is in contact with a two-phase system. At room temperature, phase separation occurred at approx. $7.6 \%(\mathrm{v} / \mathrm{v})$ isobutanol. The highest concentration used in this study was $7.4 \%$ isobutanol. Chromatography of $\left[{ }^{14} \mathrm{C}\right]$ phosphatidylcholine exchange protein on a Sephadex G-75 column in $7.4 \%$ isobutanol showed that the radioactivity peak coincided with the protein peak. This indicates that under conditions where the buffer is nearly saturated with isobutanol, phosphatidylcholine remains bound to the protein. The effect of isobutanol on the exchange activity of the protein fractions obtained after dialysis, is shown in Fig. 3. Concentrations up to $4.7 \%$ isobutanol have little significant effect, while at $7.4 \%$ the exchange activity had diminished by approximately one-third.

The influence of isobutanol on the susceptibility of protein-bound phosphatidylcholine to the action of phospholipase $A_{2}$ from bee venom and phospholipase C from B. cereus, is shown in Fig. 4A and B. It is apparent for both 


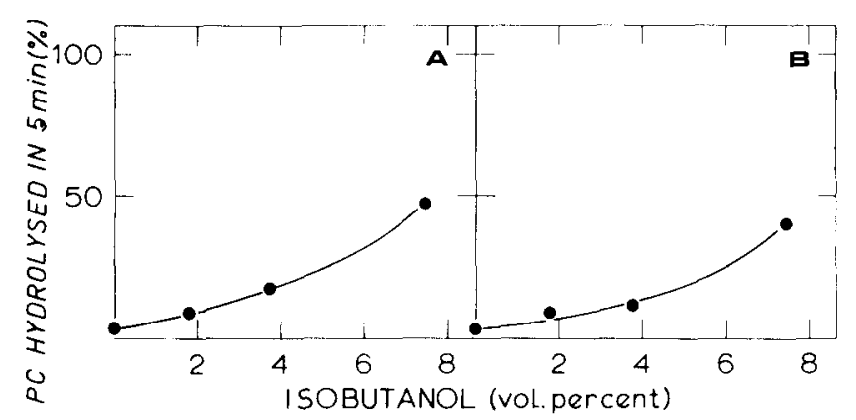

Fig. 4. The effect of isobutanol on the amounts of $\left[{ }^{14} \mathrm{C}\right]$ phosphatidylcholine, bound to the exchange protein, hydrolyzed by phospholipases during $5 \mathrm{~min}$ of incubation at $37^{\circ} \mathrm{C}$. The incubations contained 13 $\mu \mathrm{g}$ of exchange protein, spec, act. $15 \mathrm{Ci} \cdot \mathrm{mol}^{-1}$ i.e. $0.6 \mathrm{nmol}$ of phosphatidylcholine, in the presence of $1 \mu \mathrm{g}$ of phospholipase $A_{2}$ from bec venom (Fig. 4A) or $2 \mu \mathrm{g}$ of phospholipase $C$ (2 units) from $B$. cereus (Fig. 4B).

enzymes that the percent hydrolysis of $\left[{ }^{14} \mathrm{C}\right]$ phosphatidylcholine increases with increasing isobutanol concentration. Only the percent hydrolysis after 5 min incubation are given as time curves up to $30 \mathrm{~min}$ did not differ from those given in Fig. 1. In general, it appears from the hydrolysis data that isobutanol and sodium deoxycholate exert a similar effect on the phosphatidylcholine exchange protein.

\section{Effect of dioxan}

Dioxan is at all concentrations miscible with water and very effectively lowers the dielectric constant of the medium. This is in contrast to the behaviour of isobutanol. At a concentration as high as $28 \%(\mathrm{v} / \mathrm{v})$, dioxan did not delipidate the $\left[{ }^{14} \mathrm{C}\right]$ phosphatidylcholine exchange protein. This was shown by electrophoresis on polyacrylamide gels where all ${ }^{14} \mathrm{C}$ label was recovered in the protein band [3]. At concentrations above $15 \%(\mathrm{v} / \mathrm{v})$, dioxan begins to dimin-

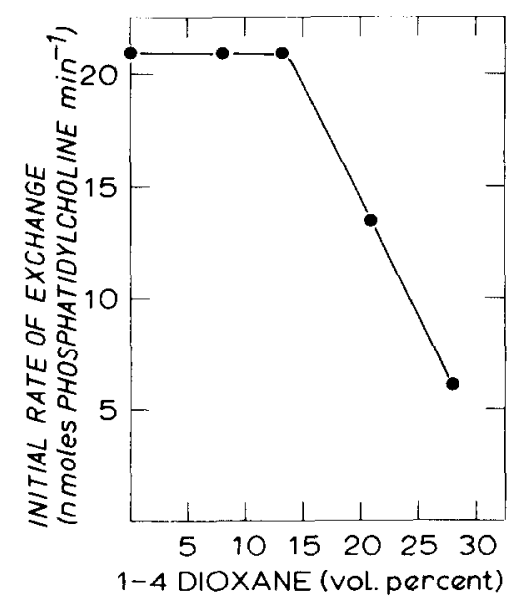

Fig. 5. The effect of dioxan on the exchange activity of the exchange protein. Samples of $50 \mu 1$ containing exchange protein $(1.5 \mu \mathrm{g})$ and different concentrations of dioxan were transferred to a liposome-microsome system (total volume $2.5 \mathrm{ml}$ ). The initial rate of exchange was measured at $37^{\circ} \mathrm{C}$. 


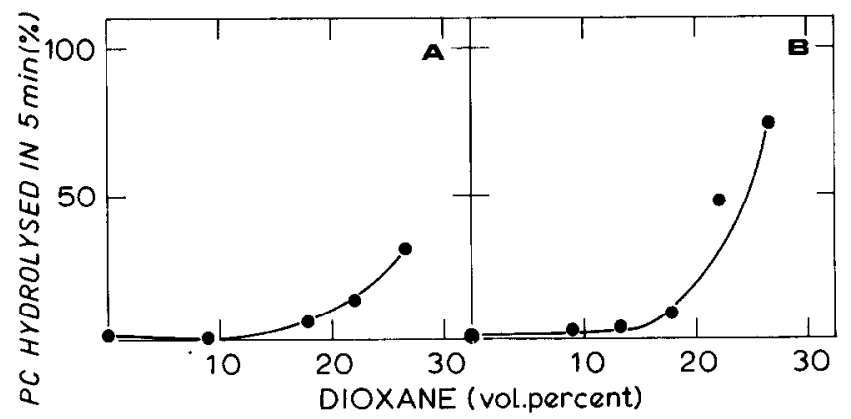

Fig. 6. The effect of dioxane on the amounts of $\left[{ }^{14} \mathrm{C}\right]$ phosphatidylcholine, bound to the exchange protein, hydrolyzed by phospholipases during $5 \mathrm{~min}$ of incubation at $37^{\circ} \mathrm{C}$. The incubations contained 15 $\mu \mathrm{g}$ of exchange protein of a specific radioactivity of $15 \mathrm{Ci} \cdot \mathrm{mol}^{-1}$ i.e. $0.7 \mathrm{nmol}$ of phosphatidylcholine, in the presence of $0.2 \mu \mathrm{g}$ phospholipase $\mathrm{A}$, from bee venom (Fig. 6A) or $1 \mu \mathrm{g}$ of phospholipase (1 unit) $\mathrm{C}$ from $B$. cereus (Fig. 6B).

ish the exchange activity of the protein (Fig. 5); at $27 \%$ dioxan, the loss of activity is $70 \%$. This inactivation of the protein is irreversible as removal of dioxan by subsequent dialysis does not reactivate the protein.

The effect of dioxan on the susceptibility of protein bound phosphatidylcholine to the hydrolytic action of phospholipase $A_{2}$ from bee venom and phospholipase $\mathrm{C}$ from B. cereus was also measured (Fig. 6A and B). For both enzymes the rate of hydrolysis is very dependent on the dioxan concentration. Below $15 \%$, hydrolysis of $\left[{ }^{14} \mathrm{C}\right]$ phosphatidylcholine is negligible; above $15 \%$, the rate of hydrolysis increases with increasing dioxan concentration. The results in Figs 5 and 6 suggest that there is a parallel between the inhibition of exchange activity and the rate of $\left[{ }^{14} \mathrm{C}\right]$ phosphatidylcholine hydrolysis.

\section{Discussion}

Phospholipases have been very helpful in obtaining information on the disposition of phospholipids in membranes [4-11] and serum lipoproteins [12-14]. Use of these enzymes has been particularly successful in establishing the asymmetric distribution of phospholipids in the human ery throcyte membrane [10]. In the present study phospholipases $A_{2}, C$ and $D$ have been used to gain insight on the localization of phosphatidylcholine bound to the exchange protein from beef liver. For each enzyme tested, phosphatidylcholine was hydrolyzed very slowly (Figs 1 and 2). By and large, the above results suggest that the phosphatidylcholine molecule is well embedded in the exchange protein structure and effectively shielded from the medium. This idea is reinforced by the fact that enzymatic hydrolysis of the phospholipid is very much stimulated by deoxycholale under conditions where the detergent concentration is too low to actually delipidate the exchange protein. This observation implies that the accessibility of the protein-bound phosphatidylcholine can be improved. Phospholipase $A_{2}$ splits off the fatty acid at the 2-position, phospholipase C the phosphorylcholine group and phospholipase D the choline group of phosphatidylcholine. In spite of this diversity of action, each phospholipase used 
can form the proper enzyme - substrate complex upon interaction with the exchange protein.

The interaction of deoxycholate with soluble protein is well documented $[34,35]$. The effect on phospholipid hydrolysis observed in this study indicates that deoxycholate also interacts with the exchange protein. Its amphipathic character makes it suitable for binding to hydrophobic sites on the protein. Given the overall hydrophobic character, this process may in fact precede an actual competition with phosphatidylcholine for a specific binding site on the protein. This would create a "lipophilic domain" on the protein in which the endogenous phosphatidylcholine molecule could dissolve. It could be envisaged that this "lipophilic domain" and the specific binding site compete for the phosphatidylcholine molecule. This notion of competition is supported by the fact that the rate of hydrolysis increases with increasing deoxycholate concentration.

In this study the effects of isobutanol on the phosphatidylcholine-exchange protein complex, under conditions where delipidation does not occur, parallel those of deoxycholate. Having marked hydrophilic and hydrophobic properties, this alcohol has a detergent-like action [25]. For this reason it is thought that isobutanol interacts with the exchange protein displacing phusphatidylcholine from its binding site and making it susceptible to phospholipase action (Fig. 4). At room temperature, isobutanol has a dielectric constant of approx. 16 [36]. This alcohol, therefore, at the highest concentration used, i.e. $7.4 \%$, will have little significant effect on the dielectric constant of the medium; however, an extensive binding to the exchange protein may lower the local dielectric constant. This may result in conformational changes to the extent that the phospholipases could act more effectively. The $30 \%$ loss of exchange activity observed with $7.4 \%$ isobutanol may be due to such a conformational change (Fig. 3). Thus, in contrast to the effect of deoxycholate where competition for a hydrophobic binding site may be prevalent, isobutanol may well exert both this competitive effect as well as an effect on the protein conformation.

Since dioxan has a very low dielectric constant $(\epsilon=2)$ and is completely miscible with water, it has been used extensively in studies on protein conformation [27]. Because dioxan lacks a hydrophobic region it will have little tendency to interact with hydrophobic sites on a protein or, for this matter, compete with phospholipids for hydrophobic sites in a lipoprotein complex. Its lowering of the dielectric constant of the medium, however, will weaken those hydrophobic interactions dictating, to a large degree, the tertiary structure of the protein $[28,29]$. In a similar manner it may be understood that dioxan at $13 \mathrm{vol} . \%$ caused hemolysis of bovine erythrocytes without any detectable extraction of lipid occurring [37]. In general, many proteins in 15-20\% dioxane begin to undergo a conformational change from an ordered state to a "random coil" [27]. It was, therefore, not entirely unexpected that in the present study the dioxane concentration had to surpass $15 \%$ before phospholipases demonstrated appreciable activity towards the protein-bound phosphatidylcholine. The exchange activity of the protein also decreased at dioxan concentrations of $15 \%$ and higher. These observations suggest that dioxan induces conformational changes in the protein to the extent that phospholipases can act. However, it 
cannot be precluded that in addition dioxan affects the binding of phosphatidylcholine to the exchange protein.

The use of phospholipases in defining the effects of deoxycholate, isobutanol and dioxan on the exchange protein necessarily limits the interpretation. Spectroscopic techniques are currently in use to expand on this interpretation.

\section{Acknowledgements}

The technical assistance of Mr P. Comfurius is gratefully acknowledged.

\section{References}

1 Kamp, H.H., Wirtz, K.W.A. and van Deenen, L.L.M. (1973) Biochim. Biophys. Acta 318, 313-325

2 Wirtz, K.W.A. (1974) Biochim. Biophys. Acta 344, 95-117

3 Kamp, H.H., Wirtz, K.W.A. and van Deenen, L.L.M. (1975) Biochim. Biophys. Acta 398, 401-414

4 Lenard, J. and Singer, S.J. (1968) Science 159, 738-739

5 Glaser, M., Simpkins, H., Singer, S.J., Sheetz, M. and Chen, S.I. (1970) Proc. Natl. Acad. Sci. U.S. 65, 721-728

6 Coleman, R., Finean, J.B., Knutton, S. and Limbrick, A.R. (1970) Biochim. Biophys. Acta 219, $81-92$

7 Laster, Y., Sabban, E. and Loyter, A. (1972) FEBS Lett. 20, 307-310

8 Op den Kamp, J.A.F., Kauerz, M.T. and van Deenen, L.L.M. (1972) J. Bacteriol. 112, 1090-1098

9 Zwaal, R.F.A., Roelofsen, B. and Colley, C.M. (1973) Biochim. Biophys. Acta 300, $159-182$

10 Verkleij, A.J., Zwaal, R.F.A., Roelofsen, B., Comfurius, P., Kastelijn, D. and van Deenen, L.L.M. (1973) Biochim. Biophys. Acta 323, 178-193

11 Rottem, S., Hasin, M. and Razin, S. (1973) Biochim. Biophys. Acta 323, 520-531

12 Ashworth, L.A.E. and Green, C. (1963) Biochem. J. 89, 561-564

13 Camejo, G. (1969) Biochim. Biophys. Acta 175, 290-300

14 Scanu, A.M. and Wisdom, C. (1972) Annu. Rev. Biochem. 41, 704-730

15 Scanu, A.M. (1965) Advances in Lipid Research (Paoletti, R. and Kritchevski, D., eds), p. 63, Academic Press, New York

16 Helenius, A. and Simons, K. (1971) Biochemistry 10, 2442-2447

17 Maddy, A.H. (1966) Biochim. Biophys. Acta 117, 193-200

18 Zahler, P, and Weibel, E.R. (1970) Biochim. Biophys. Acta 219, 320-338

19 Zwaal, R.F.A. and van Deenen, L.L.M. (1971) Chem. Phys. Lipids 4, 311-322

20 Engelman, D.M., Terry, T.M. and Morowitz, H.J. (1967) Biochim. Biophys. Acta 135, 381-390

21 Razin, S. and Barash, V. (1969) FEBS Lett. 3, 217-220

22 Simons, K., Helenius, A. and Garoff, H. (1973) J. Mol. Biol. 80, 119-133

23 Kirkpatrick, F.H., Gordesky, S.E. and Marinetti, G.V. (1974) Biochim. Biophys. Acta 345, 154-161

24 Tanford, C. (1972) J. Mol. Biol. 67, 59-74

25 Morton, K.K. (1955) Methods in Enzymology (Colowick, S.P. and Kaplan, N.O., eds), Vol. 1, p. 40, Academic Press, New York

26 Steinhardt, J. and Reynolds, J.A. (1969) Multiple Equilibria in Proteins, Academic Press, New York

27 Tanford, C. (1968) Adv. Protein Chem. 23, 121-282

28 Kauzmann, W. (1959) Adv. Protein Chem. 14, 1-63

29 Bigelow, C.C. and Krenitsky, T.A. (1964) Biochim. Biophys. Acta 88, 130-141

30 Heemskerk, C.H.T. and van Deenen, L.L.M. (1964) Proc. Koninkl. Ned. Akad. Wetenschap 67, 181191

31 Roelofsen, B., Zwaal, R.F.A., Comfurius, P., Woodward, C.B, and van Deenen, L.L.M. (1971) Biochim. Biophys. Acta 241, 925--929

32 Davis, B.J. (1964) Ann. N.Y. Acad. Sci. 121. 404-427

33 Bligh, E.G. and Dyer, W.J. (1959) Can. J. Biochem. Physiol. 37, 911-918

34 Helenius, A. and Simons, K. (1972) J. Biol. Chem. 247, 3656-3661

35 Makino, S., Reynolds, J.A. and Tanford, C. (1973) J. Biol. Chem. 248, 4926-4932

36 Åkerl8f, G. (1932) J. Am. Chem. Soc. 54, 4125-4139

37 Roelofsen, B., de Gier, J. and van Deenen, L.L.M. (1965) Proc. Koninkl. Ned. Akad. Wetenschap. 68, 249-253 